\title{
Yield and yield attributes of safflower in integrated nutrient management in black gram (Vigna mungo L.) - Safflower (Carthamus tinctorius L.) crop sequence
}

\author{
S.V. KHADTARE*, S.K. SHINDE AND V.M. TORADMAL \\ AICRP on Safflower, Zonal Agricultural Research Station (M.P.K.V.), SOLAPUR (M.S.) INDIA \\ (Email : khadtareagronomy@gmail.com)
}

\begin{abstract}
An experiment on integrated nutrient management in black gram - safflower crop sequence was conducted at DFRS, Solapur for four years (1910-11 to 1913-14) with the objective to integrate the different sources of plant nutrients for safflower based cropping system to economize fertilizer use and sustain productivity. The fertilizer dose of 100 per cent NP to both the crops in sequence recorded significantly higher seed equivalent yield $\left(2456 \mathrm{~kg} \mathrm{ha}^{-1}\right)$. Whereas, treatment with $100 \% \mathrm{~N}+50 \% \mathrm{P}+\mathrm{PSB}$ to blackgram followed by 100 per cent NP to safflower was at par with it $\left(2285 \mathrm{~kg} \mathrm{ha}^{-1}\right)$. Plant height $(103.4 \mathrm{~cm})$ and total dry matter $\left(53.41 \mathrm{~g} \mathrm{plant}^{-1}\right)$ were reported significantly superior under $100 \% \mathrm{~N}+50 \% \mathrm{P}+\mathrm{PSB}$ to blackgram and 100 per cent NP to safflower. Number of branches and number of capitulas per plant were noticed higher in treatment with 100 per cent NP to both the crops. Higher volume weight $(755 \mathrm{~g}$ ) was noticed under 100 per cent NP to blackgram and $50 \% \mathrm{~N}+$ Azotobacter $+100 \%$ P to safflower. Higher net returns of Rs. 43683/ha and B:C ratio of 2.33 were recorded under $100 \% \mathrm{~N}+50 \% \mathrm{P}+\mathrm{PSB}$ to blackgram followed by 100 per cent NP to safflower. Second in order were under $100 \% \mathrm{~N}+50 \% \mathrm{P}+\mathrm{PSB}$ to blackgram and $50 \% \mathrm{NP}+$ Azotobacter $+\mathrm{PSB}$ to safflower with Rs. 41871 and 2.27 net returns and $\mathrm{BC}$ ratio, respectively.
\end{abstract}

Key Words : Azotobacter, Crop sequence, Equivalent yield, INM, PSB

View Point Article : Khadtare, S.V., Shinde, S.K. and Toradmal, V.M. (2016). Yield and yield attributes of safflower in integrated nutrient management in black gram (Vigna mungo L.) - Safflower (Carthamus tinctorius L.) crop sequence. Internat. J. agric. Sci., 12 (2) : 158-162, DOI:10.15740/HAS/IJAS/12.2/158-162.

Article History : Received : 26.01.2016; Revised : 03.02.2016; Accepted : 06.04.2016

\footnotetext{
* Author for correspondence
} 